\title{
Analisis penerimaan retribusi obyek pariwisata di Kota Jambi
}

\author{
Ahmad Sobrowi*; Muhammad Safri; Erni Achmad \\ Prodi Ekonomi Pembangunan Fak.Ekonomi dan Bisnis Universitas Jambi \\ *E-mail korespondensi: ahmadowie29@gmail.com
}

\begin{abstract}
This study aims to: 1) determine the development of lavies received on tourism object, the number of tourist visits, the number of hotels and the number of tourist attractions in Jambi City, 2) to analyze the effect of the number of tourist visits, the number of hotels and the number of tourist attractions on the receipt of levies for tourism object in Jambi City. The data used in this research was secondary data. The data analysis method used in this research is the developments formula and multiple linear regression analysis with the eviews program. The results showed that realization of levies received aon tourism object in Jambi City increased by an average Of $35.31 \%$ with an average amount of tourist visits of $55.74 \%$, the number of hotels an average $0.50 \%$, and the number of tourist attractions an average $0,37 \%$. While the result of the t-test shows that partially the number of tourist visits and the number of hotels have a significant effect on the acceptance of tourism object fees in Jambi City with a significant value of $P<0.05$.
\end{abstract}

Keywords: Receipt of tourism object retribution, Number of tourist visits, Number of hotels, Number of tourism objects

\begin{abstract}
Abstrak
Tujuan dari penelitian ini adalah 1) Untuk mengetahui perkembangan penerimaan retribusi obyek pariwisata, jumlah kunjungan wisata, jumlah hotel, dan jumlah obyek pariwisata di Kota Jambi. 2) Untuk menganalisis pengaruh jumlah kunjungan wisatawan, jumlah hotel dan jumlah obyek wisata terhadap penerimaan retribusi obyek pariwisata di Kota Jambi. Data yang digunakan dalam penelitian ini adalah data sekunder. Metode analisis data yang digunakan dalam penelitian ini adalah rumus perkembangan dan analisis regresi linear berganda dengan bantuan program eviews. Hasil penelitian realisasi penerimaan retribusi obyek pariwisata di Kota Jambi rata-rata meningkat sebesar 35,31\% dengan jumlah kunjungan wisata rata-rata sebesar 55,74\% jumlah hotel rata-rata sebesar $0,50 \%$ dan jumlah tempat wisata rata-rata sebesar $0,37 \%$. Sedangka hasil uji t diketahui bahwa secara parsial jumlah kunjungan wisatawan dan jumlah hotel berpengaruh secara signifikan terhadap penerimaan retribusi obyek pariwisata di Kota Jambi dengan nilai signifikan $\mathrm{P}<0,05$.
\end{abstract}

Kata kunci : Penerimaan retribusi obyek wisata, Jumlah kunjungan wisata, Jumlah hotel, Jumlah obyek pariwisata

\section{PENDAHULUAN}

Pengelolaan sumber Pendapatan Asli Daerah (PAD) yang sudah ada perlu ditingkatkan dan daerah juga harus selalu kreatif dan inovatif dalam mencari serta mengembangkan potensi sumber-sumber Pendapatan Asli Daerah (PAD) yang lain, sehingga dengan semakin banyak sumber-sumber PAD yang dimiliki, maka daerah akan 
banyak memiliki sumber pendapatan yang akan dipergunakan dalam membangun daerahnya (Halim, 2004). Adanya otonomi daerah yang sudah dilaksanakan sejak beberapa tahun yang lalu, peranan dan tugas pemerintah daerah semakin bertambah. Pemerintah daerah dituntut untuk mampu mengeksplorasi segala potensi yang dimiliki daerahnya (Saleh, 2003).

Pemerintah Daerah, Dinas Kebudayaan dan Pariwisata serta masyarakat diharapkan untuk lebih peka melihat peluang-peluang yang ada dalam meningkatkan perolehan Pendapatan Asli Daerah (PAD). disamping sebagai mesin penggerak ekonomi, pariwisata adalah wahana yang menarik untuk mengurangi angka pengangguran. Dalam perekonomian nasional, pariwisata merupakan salah satu sektor yang diharap-kan mampu memberikan peningkatan pendapatan melalui penerimaan devisa. Sektor pariwisata memberi dampak yang sangat besar bagi masyarakat, terutama masyarakat yang berada di kawasan atau lokasi yang menjadi tujuan wisatawan (Rajendra dan Kismartini, 2010).

Pemungutan retribusi daerah sendiri dilakukan dengan menggunakan peraturan daerah sebagai produk hukum. Tujuan dari adanya pemungutan Retribusi Daerah sendiri adalah untuk memenuhi kebutuhan daerah serta menciptakan kesejahteraan bagi masyarakat sekitar. Dimana fungsinya adalah sebagai sumber pendapatan daerah, pengatur kegiatan perekonomian daerah, sebagai sarana stabilitas ekonomi daerah, sebagai alat untuk memeratakan pembangunan daerah serta sebagai sarana untuk membangun fasilitas daerah (Nasrul, 2010).

Kaitannya dengan Pendapatan Asli Daerah dan Pemungutan Retribusi Daerah, sektor pariwisata merupakan sektor yang memiliki potensi yang perlu dikembangkan sebagai salah satu sumber pendapatan daerah (Siahaan, 2005). Kota Jambi merupakan ibukota Provinsi Jambi, Kota Jambi sendiri banyak memiliki potensi di sektor pariwisata, hal ini akan meningkatkan Penerimaan Asli Daerah. Menurut Pertiwi (2014) sektor pariwisata merupakan komponen utamanya yang dapat menaikkan Pendapatan Asli Daerah adalah jumlah objek wisata, tingkat pemerataan fasilitas pariwisata dan jumlah wisatawan yang berkunjung.

Retribusi pariwisata merupakan pungutan yang dikenakan pada pengunjung yang datang ke tempat destinasi wisata (Purwanti dan Dewi, 2014). Retribusi ini masuk kedalam jenis retribusi jasa usaha. Tujuan utama dari peningkatan retribusi pariwisata di Kota Jambi adalah untuk meningkatkan pelayanan fasilitas tempat rekreasi, untuk meningkatkan ketertiban pengunjung serta untuk meningkatkan Pendapatan Asli Daerah melalui sektor pariwisata (Siahaan, 2005).

Kota Jambi merupakan ibu kota Provinsi Jambi. Banyak terdapat objek wisata yang mampu menjadi daya tarik pengunjung untuk datang ke Kota Jambi. Wisata sejarah berupa museum dan makam, wisata buatan berrupa taman-taman dan tugu maupun wisata alam seperti danau dan sungai. Penataan kawasan wisata tersebut oleh pemerintah daerah semakin baik.ditunjang oleh sarana pendukung seperti perhotelan dan rumah makan. Sebagai penunjang sarana pariwisata terdapat sarana akomodasi berupa hotel bintang empat, bintang tiga, bintang dua, bintang 1, hotel kelas melati, pondok wisata/home stay dan jasa akomodasi lainnya.

Selama tahun 2015-2018 perkembangan retribusi daerah di Kota Jambi mengalami perkembangan yang berfluktuasi. Tahun 2015 Triwulan IV retribusi daerah sebesar Rp.58.812.352.554 retribusi pariwisata sebesar Rp.75.080.000 jumlah kunjungan wisatawan sebesar 254.115 orang, jumlah hotel sebanyak 91 unit dan jumlah objek wisata sebanyak 140 tempat. Tahun 2016 Triwulan IV retribusi daerah di Kota Jambi sebesar Rp.80.679.063.851 retribusi pariwisata sebesar Rp.45.475.000 jumlah kunjungan wisatawan sebesar 214.483 orang, jumlah hotel sebanyak 93 unit dan jumlah objek wisata 
sebanyak 142 tempat. Tahun 2017 Triwulan IV retribusi daerah di Kota Jambi sebesar Rp.43.071.469.583 retribusi pariwisata sebesar Rp.75.205.000 jumlah kunjungan wisatawan sebesar 23.385 orang, jumlah hotel sebanyak 93 unit dan jumlah objek wisata sebanyak 145 tempat dan tahun 2018 Triwulan IV retribusi daerah di Kota Jambi sebesar Rp.40.389.059.087 retribusi pariwisata sebesar Rp.79.476.000 jumlah kunjungan wisatawan sebesar 389.684 orang, jumlah hotel sebanyak 98 unit dan jumlah objek wisata sebanyak 147 tempat.

Sumber penerimaan pendapatan disektor pariwisata tidak lepas dari jumlah kunjungan wisatawan yang datang ke obyek wisata yang ada di daerah itu. Semakin banyak pengunjung yang datang maka otomatis pendapatan daerah akan semakin meningkat dan memberikan manfaat yang besar terhadap pertumbuhan ekonomi dan Pendapatan suatu daerah. Pendapatan Asli Daerah di sektor pariwisata dengan dipengaruhi oleh fasilitas kunjungan wisata, hotel, dan objek wisatanya Jumlah kunjungan wisatawan akan meningkat ke objek pariwisata yang ada di Kota Jambi jika mereka sudah mengetahui potensi wisata yang ada (Antasari, 2013)

Keunikan objek pariwisata tersebut dan lain sebagainya wisatawan melakukan kegiatan wisata terkadang dipengaruhi oleh ciri khas yang unik yang dimaksud, melainkan juga didukung oleh kebijakan pemerintah misalnya masalah pengurusan izin wisata yang terlalu sulit dan atau tidak adanya perasaan aman bagi wisatawan jika datang berkunjung (Austriana, 2005). Fasilitas penginapan juga mempengaruhi jumlah penerimaan pemerintah dari pajak hotel atau restoran, namun fasilitas ini tergantung dari jenis wisatawan yang datang atas dasar penjelasan seperti dikemukakan (Devy dan soemanto, 2017).

\section{METODE}

\section{Jenis penelitian}

Penelitian ini merupakan penelitian deskriptif kuantitatif. Penelitian deskriptif kuantitatif merupakan penelitian dengan memperoleh data yang berbentuk angka atau data kualitatif yang diangkakan (Sugiyono, 2003).

\section{Jenis dan sumber data}

Dalam penelitian ini penulis menggunakan data sekunder yang merupakan data berkala selama dari tahun 2015-2018. Sumber data yang digunakan dalam penelitian ini bersumber dari Dinas Kebudayaan dan Pariwisata Kota Jambi, Dinas Pendapatan Daerah Kota Jambi, BPS Kota Jambi dan BPKAD Kota Jambi.

\section{Metode analisis data}

Untuk menjawab tujuan pertama digunakan rumus berikut (Rajendra dan Kismartini, 2010) :

\section{Dimana :}

$$
\mathrm{Gx}=\frac{\mathrm{Xt}-\mathrm{Xt} \mathbf{1}}{\mathrm{Xt} 1} \times 100
$$

\footnotetext{
$\mathrm{Gx}=1$. penerimaan retribusi obyek pariwisata

2. Jumlah kunjungan wisata

3. Jumlah Hotel

4. Jumlah obyek pariwisata

$\mathrm{Xt}=$ Tahun Sekarang

Xt-1 = Tahun Sebelumnya
} 
Untuk menjawab tujuan yang kedua, digunakan rumus regresi linear berganda (Nasrul, 2010) yang diambil dari :

$$
\mathbf{Y}=\beta_{0}+\beta_{1} X_{1}+\beta_{2} X_{2}+\beta_{3} X_{3}+e
$$

Keterangan:

$\mathrm{Y} \quad=$ ROP (retribusi obyek pariwisata)

$\mathrm{X} 1=\mathrm{JKW}$ (jumlah kunjungan wisatawan)

$\mathrm{X} 2=\mathrm{JH}$ (jumlah hotel)

$\mathrm{X} 3=\mathrm{JOP}$ (jumlah obyek pariwisata)

Bo $\quad=$ Konstanta

$\beta_{1}, \beta_{2}=$ Koefisien elastisitas

e $\quad=$ Standar error

\section{Uji F-statistik}

Uji F-Statistik menunjukan apakah semua bebas yang dimasukkan dalam model mempunyai pengaruh secara bersama - sama terhadap variabel dependen. Uji-F dapat dirumuskan n sebagai berikut:

F test $=\frac{R^{2} /(K-10}{\left(1-R^{2}\right) /(n-K)}$

Dimana :

$\mathrm{R}=$ Koefisien determinasi

$\mathrm{K}=$ Banyaknya variabel bebas

$\mathrm{N}$ = Banyaknya jumlah observasi

Dengan pengambilan keputusan jika Prob (F statistik ) < signifikan level 0,5 $(\alpha=5 \%)$, maka itu $\mathrm{H}_{0}$ ditolak Ha diterima. Jika Prob (F statistik ) > signifikan level 0,5 $(\alpha=5 \%)$, maka itu $\mathrm{H}_{0}$ diterima $\mathrm{H}_{1}$ diterima.

\section{Uji t-statistik}

Uji statistik digunakan untuk menguji signifikan variabel independen terhadap variabel dependen dalam persamaan secara parsial. Bila signifikan berarti secara statistik ini menunujukan bahwa variabel bebas mempunyai pengaruh secara parsial terhadap variabel tidak bebas. Nilai thitung dapat diperoleh dengan formula sebagai berikut.

$$
\mathbf{t}=\frac{\beta i-\beta \beta i-\beta}{S_{b} \quad S_{b}}
$$

Dimana :

$\beta_{1}=$ Koefisien variabel independen ke-i

$\beta=$ Nilai hipotesis

$\mathrm{S}_{\mathrm{b}} \quad$ = simpangan baku

Dalam uji-t yang digunakan adalah satu arah, hipotesisi yang digunakan adalah jika $t_{\text {hitung }}>t_{\text {tabel, }}$ maka $\mathrm{H} 0$ ditolak yang berarti variabel bebas tidak memiliki pengaruh yang signifikan terhadap variabel terikat. Jika $t_{\text {hitung }}<\mathrm{t}_{\text {tabel, }}$, maka HO ditolak yang berarti variabel bebas memiliki pengaruh yang signifikan terhadap variabel terikat. 


\section{Koefisien determinasi $\left(\mathbf{R}^{\mathbf{2}}\right)$}

Koefisien Determinasi $\left(\mathrm{R}^{2}\right)$ mempunyai kegunaan, yaitu sebagai ukuran ketepatan suatu garis yang diterapkan pada suatu kelompok data hasil observasi ( a measure of the goodness of fit ). Makin besar nilai $\mathrm{R}^{2}$ maka semakin tepat atau cocok garis regresi, dan sebaliknya apabila nilai $\mathrm{R}^{2}$ semakin kecil, maka semakin tidak tepat gari regresi tersebut untuk mewakili data hasi observasi. Nilai $\mathrm{R}^{2}$ antara 0 dan $1 . \mathrm{R}^{2}$ juga digunakan untuk menentukan derajat atau kekuatan hubungan antara variabel bebas dengan tidak bebas, digunakan rumus

$$
R^{2}=\frac{1-\sum e i}{\sum e i}
$$

Dimana apabila koefisien determinasi: 1).Jika $\mathrm{R}^{2}=1$, artinya hubungan antara variabel bebas dengan variabel tidak bebas adalah sempurna dan positif, 2). $R^{2}=0$, artinya hubungan antara variabel bebas dengan variabel tidak bebas mendekati nol, maka hubungan antara variabel bebas dengan variabel tidak bebas adalah lemah sekali, 3). $\mathrm{R}^{2}=$ -1 , artinya hubungan antara variabel bebas dengan tidak bebas adalah negatif.

\section{HASIL DAN PEMBAHASAN}

\section{Penerimaan retribusi obyek pariwisata}

Adapun penerimaan retribusi obyek pariwisata di Kota Jambi selama tahun 20152018 sebagai berikut.

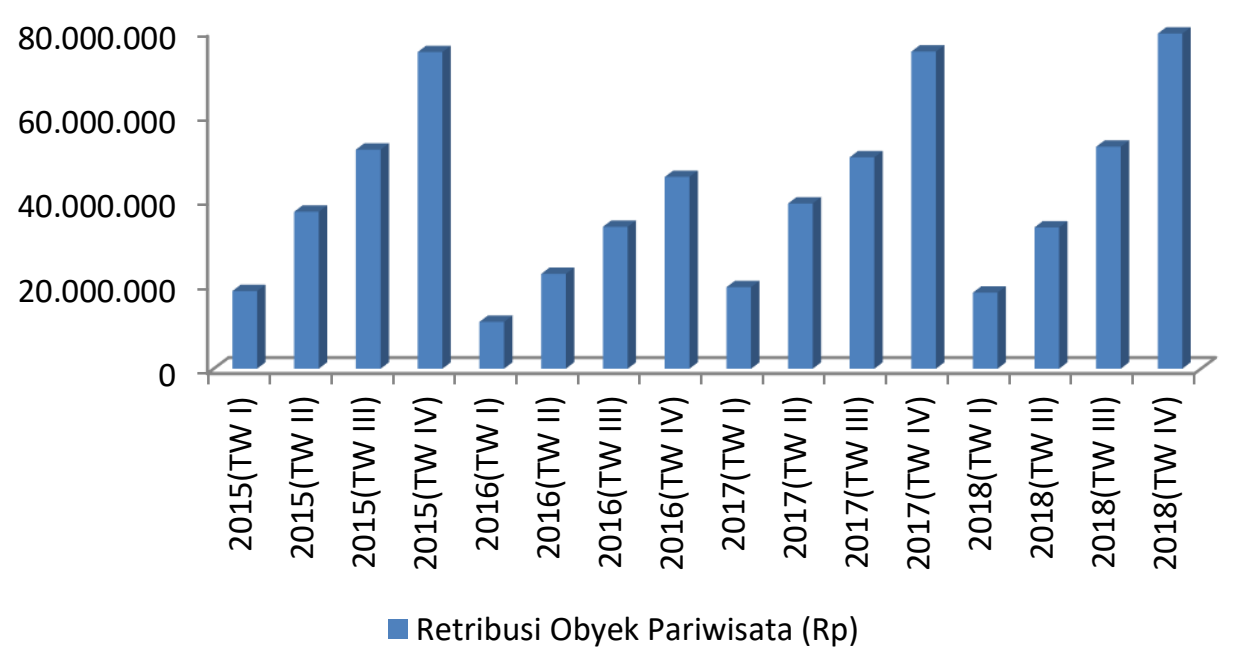

Gambar 1. Perkembangan penerimaan retribusi obyek pariwisata

Naik turunnya angka perkembangan penerimaan retribusi obyek pariwisata di Kota Jambi dapat disebabkan oleh beberapa faktor. Salah satu faktor yang sangat berperan adalah jumlah kunjungan wisatawan ke objek wisata yang ada dalam wilayah pemerintahan di Kota Jambi. Selain itu, jumlah objek wisata dan pelayanan yang diberikan juga mendukung minat wisatwan untuk berkunjung ke tempat-tempat pariwisata yang ada di Kota Jambi. Jika minat wisatawan tinggi maka retribusi tempat pariwisata juga akan tinggi. Hal ini dikarenakan retribusi pariwisata dipungut karena adanya kedatangan pengunjung ke objek wisata.

\section{Jumlah kunjungan wisata}

Jumlah kunjungan wisata di Kota Jambi selama tahun 2015-2018 berfluktuatif. Jumlah kunjungan wisata di Kota Jambi juga dapat dilihat pada Grafik 2 sebagai berikut. 


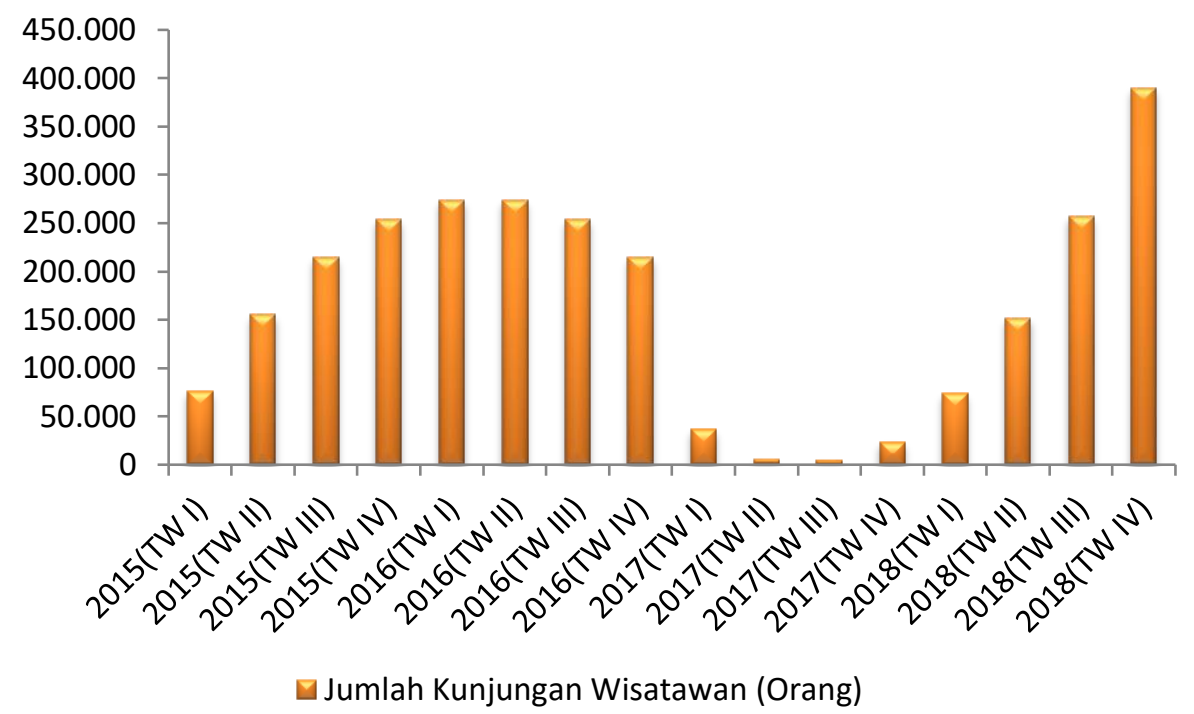

Gambar 2. Perkembangan jumlah kunjungan wisata

Jumlah kunjungan wisata yang berfluktuatif dapat disebabkan oleh beberapa hal, seperti kondisi perekonomian masyarakat serta kondisi tempat wisata yang menjadi tujuan pengunjung. Daya tarik dari tempat wisata, ketersediaan sarana dan prasarana termasuk transportasi, akses menuju tempat wisata dan fasilitas serta pelayanan yang diberikan oleh tempat wisata menjadi aspek yang menentukan banyak atau sedikitnya jumlah kunjungan wisata ke suatu tempat wisata.

\section{Jumlah hotel}

Angka perkembangan jumlah hotel di Kota Jambi selama tahun 2015-2018 mengalami perkembangan yang tidak begitu besar. Selanjutnya jumlah hotel di Kota Jambi juga dapat dilihat pada Grafik 3.

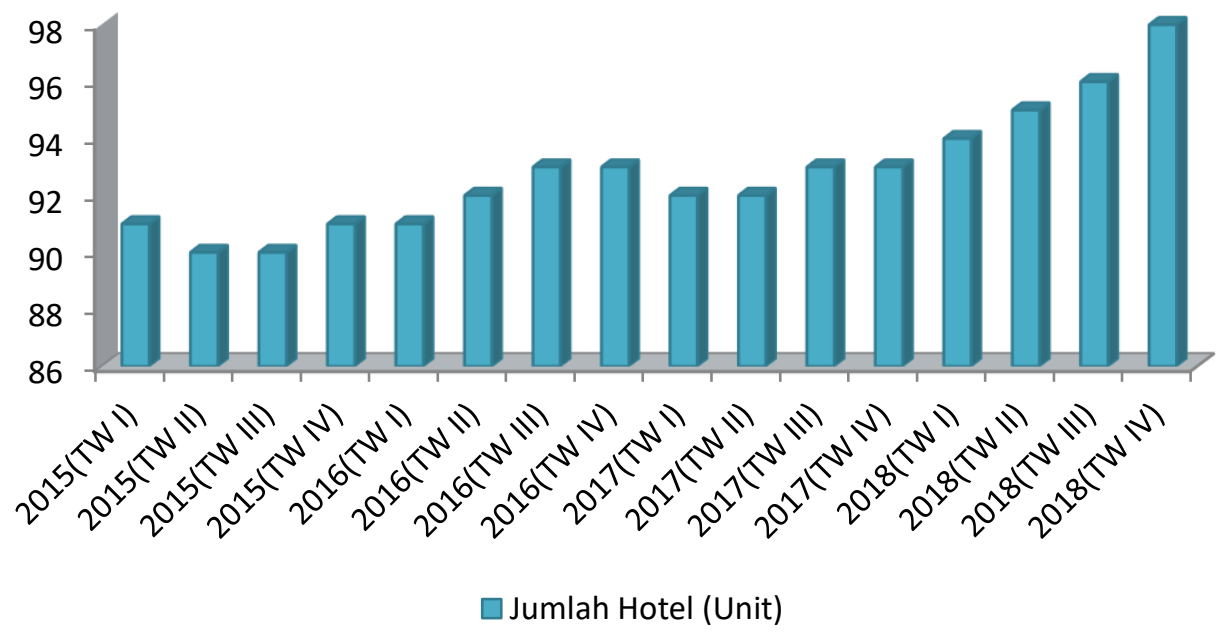

Gambar 3. Perkembangan jumlah hotel di Kota Jambi

\section{Jumlah obyek wisata}

Jumlah obyek wisata di Kota Jambi selama tahun 2015-2018 tidak mengalami perkembangan yang signifikan. Hal ini juga dapat dilihat pada Grafik 4 berikut ini. 


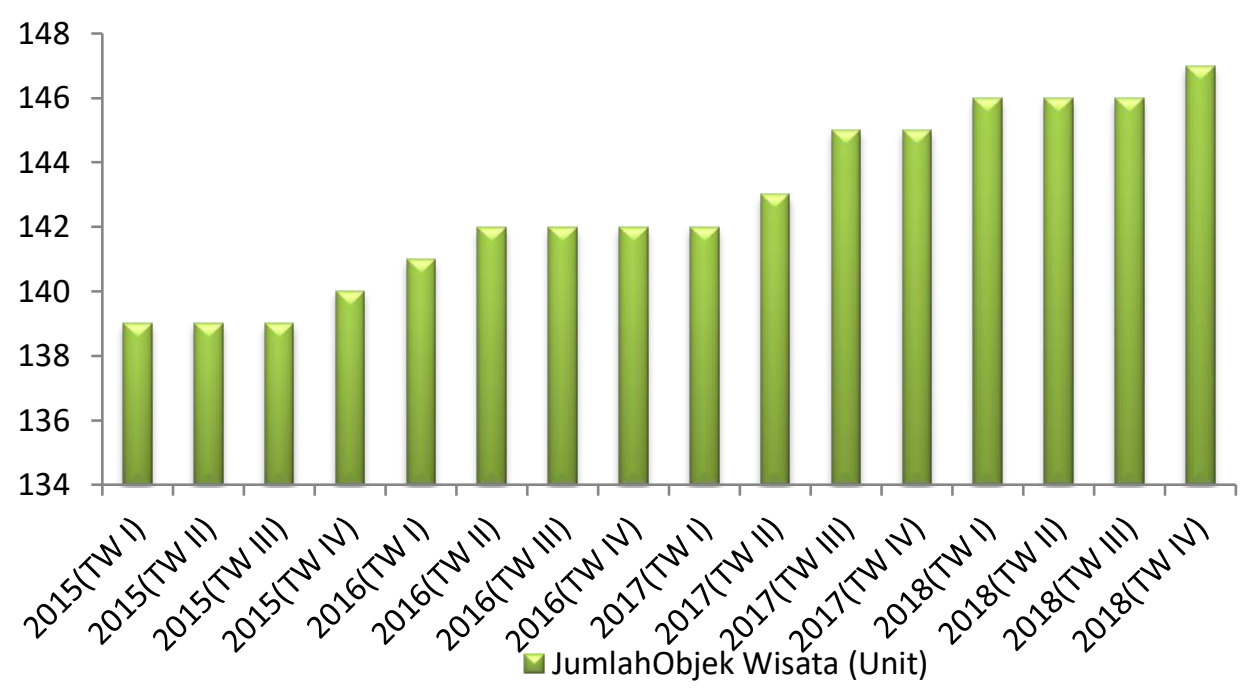

Gambar 4. Perkembangan jumlah obyek wisata

\section{Hasil estimasi regresi linear berganda}

Analisis regresi linear berganda dilakukan dengan tujuan untuk mengetahui pengaruh dari jumlah kunjungan wisatawan, jumlah hotel dan jumlah obyek wisata terhadap penerimaan retribusi obyek pariwisata di Kota Jambi. Adapun hasil regresi linear berganda dalam penelitian ini sebagai berikut.

Tabel 1. Hasil regresi linear berganda

\begin{tabular}{lrrrr}
\hline \hline \multicolumn{1}{c}{ Variable } & Coefficient & Std. Error & t-Statistic & Prob. \\
\hline \hline \multicolumn{1}{c}{ Constanta } & -13.69097 & 11.07961 & -1.235691 & 0.2402 \\
JML Kunjungan Wisata & 0.225260 & 0.058810 & 3.830327 & 0.0024 \\
$\quad$ Jumlah Hotel & 0.402392 & 0.177260 & 2.270072 & 0.0424 \\
\multicolumn{1}{c}{ JML Obyek Wisata } & 8.979382 & 5.173470 & 1.735660 & 0.1082 \\
\hline \hline R-squared & 0.643000 & Mean dependent var & 7.555625 \\
Adjusted R-squared & 0.553750 & S.D. dependent var & 0.253087 \\
S.E. of regression & 0.169067 & Akaike info criterion & -0.504727 \\
Sum squared resid & 0.343003 & Schwarz criterion & -0.311580 \\
Log likelihood & 8.037815 & Hannan-Quinn criter. & -0.494836 \\
F-statistic & 7.204484 & Durbin-Watson stat & 1.515857 \\
Prob(F-statistic) & 0.005055 & & \\
\hline \hline
\end{tabular}

Sumber : Data diolah, 2020

Berdasarkan hasil tersebut, maka persamaan regresi yang digunakan dalam penelitian ini adalah :

$$
Y=-13,69097+0,225260 X_{1}+0,402392 X_{2}+8,979382 X_{3}
$$

\section{Uji asumsi klasik}

\section{Uji multikolinearitas}

Hasil uji multikolinearitas menunjukkan bahwa jumlah kunjungan wisatawan memiliki nilai VIF sebesar 1,003506, jumlah hotel sebesar 1,093741, dan jumlah obyek wisata sebesar 1,070971. Sehingga dapat disimpulkan bahwa model regresi yang 
digunakan dalam penelitian ini tidak mengalami multikolinearitas atau tidak mengandung korelasi antara variabel dependen.

\section{Uji heterokesdasitas}

Uji heteroskedasitas dalam penelitian ini menggunakan uji Breusch dengan nilai probability $\mathrm{F}_{\text {hitung }}>\alpha=5 \%$ maka tidak terindikasi adanya gelaja heterokesdasitas. Hasil dari uji heterokedastisitas menunjukkan bahwa nilai $F_{\text {hitung }}$ sebesar $0,7531\left(F_{\text {hitung }}>\alpha=5 \%\right.$ ) sehingga model regresi dalam penelitian ini tidak terindikasi adanya gelaja heterokedastisitas dan persamaannya valid untuk digunakan.

\section{Uji autokorelasi}

Nilai probability yang digunakan dalam uji autokorelasi adalah jika nilai dW lebih besar dari nilai $\mathrm{dU}(\mathrm{dW}>\mathrm{dL})$ pada $\alpha=5 \%$ maka tidak terindikasi adanya gejala autokorelasi. Hasil uji autokorelasi menunjukkan bahwa nilai dW sebesar 2,525357. Selanjutnya nilai ini dibandingkan dengan nilai tabel signifikansi 5\% dimana jumlah sampel $\mathrm{n}=16$ dan jumlah variabel independen $3(\mathrm{k}=3)$ maka diperoleh nilai dU sebesar 1,8159 . Nilai dW tersebut lebih besar dari nilai dU $(2,525357>1,8159)$ sehingga dapat disimpulkan bahwa model regresi dalam penelitian ini tidak terindikasi adanya gelaja autokorelasi.

\section{Uji normalitas}

Uji normalitas dimaksudkan untuk mengetahui apakah data yang akan dianalisis berbentuk sebaran normal atau tidak. Pengujian ini dilakukan dengan menggunakan Jarque-Bera test. Jika nilai probability $>\alpha=5 \%$ maka persamaan dalam penelitian ini berdistribusi normal. Hasil uji normalitas dalam penelitian ini menunjukkan bahwa nilai

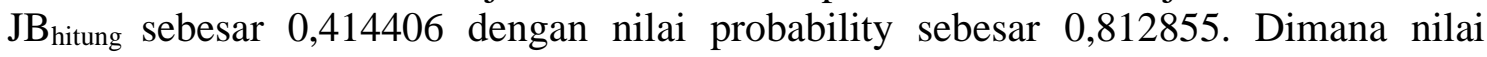
probability tersebut lebih besar dari $5 \%(\mathrm{p}>\alpha=5 \%)$ sehingga dapat disimpulkan bahwa residual berdistribusi normal dan asumsi klasik tentang kenormalan telah terpenuhi.

\section{Uji statistik}

\section{Uji simultan (Uji F)}

Hasil penelitian menunjukkan bahwa nilai $F_{\text {hitung }}$ sebesar 7,204484 sedangkan nilai $F_{\text {tabel }}$ sebesar 3,41 pada taraf $\alpha=5 \%$ dengan derajat kebebasan $(\mathrm{df}=\mathrm{n}-\mathrm{k})$ sebesar 13 . Dengan demikian $F_{\text {hitung }}>F_{\text {tabel }}$ yaitu 7,204484 $>$ 3,41 yang artinya jumlah kunjungan wisatawan, jumlah hotel dan jumlah obyek wisata secara simultan atau bersama-sama berpengaruh terhadap retribusi pariwisata Kota Jambi.

\section{Uji parsial (Uji t)}

Hasil uji t nilai signifikansi dari variabel jumlah kunjungan wisatawan sebesar 0,0024 dengan nilai signifikansi lebih kecil dari $\alpha=5 \%$. Hal ini menunjukkan bahwa jumlah kunjungan wisatawan berpengaruh secara signifikan terhadap retribusi pariwisata Kota Jambi. Hal ini dikarenakan ketika jumlah kunjungan wisatawan tinggi maka pungutan biaya atas jasa dan pelayanan suatu objek wisata juga akan tinggi.

Hasil uji t menunjukkan bahwa nilai signifikansi dari variabel jumlah hotel sebesar 0,0424 atau lebih kecil dari $\alpha=5 \%$, sehingga jumlah hotel berpengaruh secara signifikan terhadap retribusi pariwisata di Kota Jambi. Hal ini diduga karena ketersediaan jumlah hotel dalam suatu wilayah akan menjadi bahan pertimbangan bagi wisatawan untuk 
melakukan perjalanan wisata ke suatu wilayah. Jika hotel yang tersedia di suatu wilayah memadai maka wisatawan akan antusias untuk berkunjung, begitu juga sebaliknya.

Hasil uji-t pada analisis regresi linear berganda menunjukkan bahwa nilai signifikansi jumlah obyek wisata sebesar 0,1082. Hal ini menunjukkan bahwa nilai signifikansi dari jumlah obyek wisata lebih besar dari 0,05 (P>0,05) sehingga jumlah obyek wisata berpenagruh tidak signifikan terhadap retribusi obyek pariwisata di Kota Jambi. Hal ini diduga karena banyaknya jumlah obyek wisata jika tidak diimbangi dengan ketersediaan sarana dan prasarana wisata yang memadai, maka minat pengunjung untuk datang menikmati obyek wisata akan rendah.

\section{Koefisien determinasi $\left(\mathbf{R}^{2}\right)$}

Hasil perhitungan menunjukkan bahwa nilai koefisien determinasi dalam penelitian ini sebesar 0.643000 atau sebesar $64,30 \%$. Hal ini menunjukkan bahwa variabel jumlah kunjungan wisata, jumlah hotel dan jumlah obyek wisata mempengaruhi retribusi obyek pariwisata di Kota Jambi sebesar 64,30\%. Sedangkan sebesar 35,70\% dipengaruhi oleh faktor lain yang tidak termasuk kedalam penelitian ini.

\section{KESIMPULAN DAN SARAN}

\section{Kesimpulan}

Realisasi penerimaan retribusi obyek pariwisata di Kota Jambi rata-rata meningkat sebesar $35,31 \%$ dengan jumlah kunjungan wisata rata-rata sebesar 55,74\%. Jumlah kunjungan wisatawan dan jumlah hotel diKota Jambi berpengaruh secara signifikan dan positif terhadap retribusi tempat pariwisata di Kota Jambi, sedangkan jumlah objek wisata berpengaruh tidak signifikan terhadap retribusi tempat pariwisata di Kota Jambi.

\section{Saran}

Untuk meningkatkan realisasi penerimaan tempat wisata di Kota Jambi yang masih relative rendah disarankan kepada pemerintah dan para pihak terkait agar dapat secara intensif meningkatkan penataan objek wisata alam (DAS Batanghari), wisata religius dan budaya di bagian seberang Kota Jambi serta wisata buatan yang terintegrasi terhadap wisata alam yang dapat mengakomodir manfaat lingkungan dan kesempatan kerja bagi warga Kota Jambi.

Untuk meningkatkan jumlah kunjungan wisatawan maka pihak terkait disamping penataan prasarana objek fisik pariwisata juga dapat meningkatkan jenis dan modifikasi wisata religius dan budaya yang dapat memancing kedatangan jumlah wisatawan. Sedangkan untuk hotel-hotel atau penginapan yang ada, kiranya dapat dilengkapi dengan desain bangunan yang menonjolkan budaya khas Jambi dengan peningkatan fasilitas hotel yang tidak bertentangan dengan norma dan budaya yang ada.

\section{DAFTAR PUSTAKA}

Antasari, N. L. S. (2013). Peran industri pariwisata terhadap penerimaan pendapatan asli daerah Kabupaten Gianyar. Jurnal Perhotelan Dan Pariwisata, 3 (36): 1-10.

Austriana, I. (2005). Analisis faktor yang mempengaruhi penerimaan daerah dari sektor pariwisata. Skripsi. Fakultas Ekonomi dan Bisnis, Universitas Diponegoro: Semarang.

Devy, H.A dan R.B. Soemanto. (2017). Pengembangan obyek dan daya tarik wisata alam sebagai daerah tujuan wisata di Kabupaten Karanganyar. Jurnal Sosiologi Fakultas Ilmu Sosial dan Politik. 32 (1), 34-44. 
Halim, A. (2004). Manajemen keuangan daerah. (UPP) AMP YKPN: Yogyakarta.

I Romiyati, Y Yulmardi, A Bhakti. (2019).Faktor-faktor yang mempengaruhi penerimaan retribusi daerah di Kota Jambi, Jurnal Paradigma Ekonomika, 14 (2), 83-96

J Junaidi, A Amril, JK Edi, M Ridwansyah, D Hastuti, S Aminah. (2019). Arahan zonasi pada pengembangan agrowisata berbasis community based Tourism Desa Renah Alai, Jurnal Inovasi, Teknologi dan Dharma Bagi Masyarakat, 1 (1), 29-36

Nasrul, Q. (2010). Analisis penerimaan daerah dari sektor pariwisata di kota semarang dan faktor-faktor yang mempengaruhinya. Skripsi. Fakultas Ekonmi, Universitas Diponegoro: Semarang.

Pertiwi. (2014). Pengaruh jumlah kunjungan wisatawan, retribusi obyek wisata, dan PHR terhadap pendapatan asli daerah. Kabupaten Gianyar. E-Jurnal EP Unud, 3 (3) : 76-123.

Purwanti, N.D., dan Dewi, R.M. (2014). pengaruh jumlah kunjungan wisatawan terhadap pendapatan asli daerah Kabupaten Mojokerto tahun 2006-2013, Jurnal ilmiah Program Studi Pendidikan Ekonomi. Fakultas Ekonomi: Universitas Negeri Surabaya. 1 (2): 1-15.

Rajendra, Y dan Kismartini. (2010). Kajian perkembangan retribusi pariwisata di Kabupaten Kendal. Artikel Ilmiah. Fakultas Ilmu Sosial dan Ilmu Politik, Universitas Diponegoro: Semarang.

S Amin, D Hastuti.(2020). Analysis of the Local Potential Attraction in Sipin Lake Jambi City. Talent Development \& Excellence 12 (1), 2315-2332

Saleh, S. (2003). Kemampuan pinjam daerah Kabupaten dan Kota di Indonesia. Media Ekonomi dan Bisnis: Semarang.

Siahaan, M.P. (2005). Pajak daerah dan retribusi daerah. Raja Grafindo. Jakarta.

Sugiyono. (2003). Metode penelitian adminsitrasi, Alfabeta: Bandung. 